E PRESS

\title{
Out of the Ashes: \\ Destruction and Reconstruction of East Timor
}

\section{Abstract for chapter 9}

\section{Author: Harold Crouch}

'The TNI and East Timor policy' examines the events in the lead up to the referendum and the events after the referendum with specific reference to the violence that occurred and its perpetrators.

The focus is on the perceptions of the Indonesians towards East Timor, which was seen as a failure of foreign policy for which diplomats were to blame rather than as a result of the forced integration of East Timor and the accompanying military repression. The autonomy proposal and the popular consultation are considered, along with the role of the military in the referendum and the ensuing post-referendum destruction.

\section{Keywords}

5 May Agreement, Abilio Soares, Ali Alatas, autonomy, Bishop Belo, Catholics, Domingo Soares, General Wiranto, Interfet, João Tovares, José Ramos Horta, militia, MPR, Muslims, popular consultation, President Soeharto, TNI, UNAMET, Xanana Gusmão 


\section{9 \\ The TNI and East Timor policy \\ Harold Crouch}

As long as President Soeharto remained in power, there was no possibility that the Indonesian government would consider the prospect of an independent East Timor. Soeharto, after all, had been responsible for the initial invasion and could hardly have been expected to disown what he regarded as one of his regime's important achievements. For almost a quarter of a century, Indonesia had borne the world's condemnation while the Indonesian military (TNI) ${ }^{1}$ had reduced the guerilla resistance to a few hundred and the captured resistance leader himself had admitted that his forces had been defeated militarily. Although anti-Jakarta demonstrations broke out from time to time in East Timor and occasional military clashes took place, there was no possibility that Indonesia's military forces could be driven out by the resistance forces.

Soeharto's attitude was supported by the TNI. The standard military view was that the armed forces had saved the people of East Timor from communism and protected the rest of Indonesia from possible communist infiltration through East Timor. However bizarre that interpretation may have seemed to the rest of the world, most officers were proud of the sacrifices they had made for the nation in East Timor. They also believed that Indonesia's military intervention in

1 At that time the military was still known as the Armed Forces of the Republic of Indonesia (ABRI). It was renamed as the Indonesian National Military (TNI) after the separation of the police in April 1999. I wish to thank Kumiko Mizuno and Marcus Mietzner for their helpful comments. 
1975 had saved the East Timorese from civil war and were convinced that civil conflict would start again if they withdrew. An overwhelming majority of army officers had served in East Timor at one time or another and some had served three or four tours of duty there. Many officers also felt a deep emotional attachment to East Timor as the place where several thousand Indonesian soldiers had died. ${ }^{2}$

Although the Soeharto government saw no need to offer concessions to world opinion on the East Timor issue, there were, however, signs of growing public scepticism in Indonesia itself. It needs, however, to be emphasised that the average educated middle-class Indonesian citizen had never given much attention to East Timor, whose people made up less than half of one per cent of the total population. For most Indonesians, East Timor was - if it was a problem at all - only one problem among many and by no means the most important. It was only after the Dili massacre in November 1991 - which happened to coincide with the period of political keterbukaan (openness) - that readers of the Indonesian press became more aware of military repression in East Timor. But, even then, they tended to see military repression in East Timor as part of an Indonesia-wide phenomenon and not a consequence of the forced integration of that province. Even prodemocracy activists often seemed to believe that the key problem was to democratise Indonesia itself and then the East Timorese would be happy to remain with Indonesia.

Although most educated Indonesians showed little sympathy for East Timorese opposition to Indonesian rule, there was an increasing sense that the East Timor issue was causing more trouble than it was worth. Indonesians did not share the foreign perception of the East Timor issue as a case of invasion and military occupation. Instead they considered it as no more than a nuisance - in the words of the Foreign Minister, Ali Alatas, 'a pebble in the shoe' - caused by a noisy urban minority unrepresentative of the predominantly rural people of East Timor. Many Indonesians were dismayed because the East Timorese showed no gratitude for the many hospitals, schools and kilometres of roads provided by the Indonesian government. Why, they increasingly asked, should we continue to be the target of world

2 In September 1999, General Wiranto said that 1500 service personnel had been killed in East Timor and 2400 wounded or disabled (Kompas, 13 September 1999). 
criticism just for the sake of the East Timorese who do not appreciate Indonesian generosity? The Jakarta Post expressed this mood in 1995 when it said in an editorial:

We are detecting the spread of a kind of 'East Timor fatigue' among many Indonesians. Questions such as, how much longer will the East Timor problem continue to haunt us, or, why does East Timor continue to be a running sore even after almost 20 years of integration, are examples of this feeling. ${ }^{3}$

Nevertheless, East Timor was commonly perceived as essentially a failure of foreign policy for which Indonesia's hapless diplomats were blamed rather than a result of the forced integration of East Timor and accompanying military repression.

Lack of sympathy for East Timorese aspirations was particularly apparent in the comments of Muslims who had little sense of identity with the predominantly Catholic East Timorese. The modernist Muslim intellectual, Dawam Rahardjo, complained about 'the impression that the central government treats East Timor as "a favoured son" in the allocation of its budget'. As more Indonesian Muslim civil servants and security personnel moved into East Timor, they became the focus of East Timorese resentment which was expressed in attacks on mosques, violence against 'Muslim' traders in markets and large-scale rioting in September 1995 which forced hundreds to flee East Timor. The Muhammadiyah leader, Amien Rais, complained that Indonesians went to East Timor to provide milk but were given poison in return. ${ }^{5}$ Jakarta Muslims initially demanded that the government impose stricter security measures on 'sectarian Catholics' in East Timor but later some seemed to be concluding that the East Timorese were just too different to be accepted in Indonesia. For example, at the end of 1996, Amien Rais proposed that:

if the East Timorese still want a referendum then I would say it is better to give them a chance to have a referendum. Even if they want to separate from Indonesia. Let it be. It's better for them and better for Indonesia too. I think my government has done its best. ${ }^{6}$

3 'The East Timor Issue', Jakarta Post, 28 September 1995.

4 Dawam Rahardjo, 'Hadiah Nobel dan Diplomasi Indonesia' (Tempo, 28 October 1996).

5 Gatra, 21 September 1995.

6 Patrick Walters, 'Let E Timor decide: Muslim chief', Australian, 11 December 1996. 
And, writing in the Muslim newspaper, Republika, another Muslim intellectual, Dr Indria Samego, argued that:

In recent times we have seen how developmental initiatives initially intended to Indonesianise the people of East Timor have only strengthened the determination of a number of critical leaders to fight for self-determination in the territory.

If all else fails, he concluded,

Rather than become the target of international criticism, why don't we simply give the opportunity to the East Timorese society to determine their own future?

These sentiments were common among members of the Indonesian Association of Muslim Intellectuals (ICMI) and its thinktank (CIDES) with which the newspaper, Republika, was associated. Amien Rais, Dawam Rahardjo, Indria Samego and Dewi Fortuna Anwar (who later became President Habibie's foreign policy advisor) were all associated with ICMI whose general chairman was B.J. Habibie. This is not to claim that Habibie himself shared their views at that time but only to note that these ideas were already being discussed before 1998 in the circles from which he drew his advisors after becoming president.

Even within the military there were some indications of support for a new approach to East Timor, although no military officers appeared to have envisaged the possibility of eventual independence. In 1994, the East Timor resort commander, Colonel Johny Lumintang, admitted to a foreign journalist that 'It is true we have not got the sympathy of the people' and described the Dili massacre as an 'expensive lesson'. ${ }^{8}$ Later in the year, Maj. Gen. Adang Ruchiatna, the Commander of the Udayana Military Region IX, based in Bali and covering East Timor, speaking at a seminar organised by the Indonesian Institute of Sciences (LIPI), indicated his support for the granting of special status to East Timor. 'The 'special status' proposal

7 Indria Samego, 'Politisasi Timtim', Republika, 28 and 29 November 1996. 8 Lindsay Murdoch, 'Timor not tamed, Indonesians admit', Age, 18 April 1994.

9 João Mariano de Sousa Saldanha, The Political Economy of East Timor Development (1994), pp.371-372; Australian, 16 September 1994. 
was supported by the East Timor governor, Abilio Soares, who had close military links, especially with President Soeharto's son-in-law, then Colonel Prabowo Subianto. In late 1994 Prabowo discussed the proposal with Xanana Gusmão in gaol but at the end of the year the idea was killed when Soeharto declared his opposition. Nevertheless, indications of military awareness of a need for a changed approach continued to be revealed in occasional public comments by retired officers. For example, Maj. Gen. Z.A. Maulani, an advisor to Habibie, acknowledged that 'the problem at present is that part of the society there feels that it has been treated unjustly' and that 'they believe that our government violates East Timorese cultural values' - although he made it clear at that time that he did not favour a referendum. ${ }^{10}$

It was, however, only after the fall of the Soeharto regime in May 1998 that Indonesian policy began to change. Indonesia's economic condition was desperate when President Habibie came to power and its international reputation had been severely besmirched by anti-Chinese rioting which had culminated in the huge riot of May 1998 that triggered Soeharto's resignation. President Habibie had never shown any particular concern about East Timor during his two decades as a cabinet minister under Soeharto but he was acutely aware of the way in which it continued to harm Indonesia's international reputation and its potential for creating new problems. As part of his effort to improve Indonesia's international image, he decided that something had to be done about East Timor. Thus, he initially proposed that East Timor be granted full autonomy and then proposed the 'popular consultation' that ended with an overwhelming vote in effect for independence.

\section{The autonomy proposal}

The possibility of a change in policy was hinted within four days of Habibie's installation as president, when his new Minister of Justice, Muladi, suggested it was now time for Indonesia to make East Timor a 'special region'. ${ }^{11}$ Habibie himself quickly asserted in a CNN interview that 'East Timor is an integrated part of the republic ... There is no

10 Z.A. Maulani, 'Kerikil Ini Menyakitkan', Gatra, 14 December 1996. After Habibie succeeded to the presidency, Maulani was appointed as head of the State Intelligence Agency (BAKIN).

11 Kompas, 25 May 1998. 
need for a referendum, it is Indonesia'. ${ }^{12}$ However, a week later in an interview with the $\mathrm{BBC}$, he casually announced that ' $\mathrm{I}$ am ready to consider giving East Timor special status like Jakarta, Aceh and Yogyakarta'. ${ }^{13}$ It seems that Habibie's offer during the BBC interview was spontaneous and had taken the Foreign Minister, Ali Alatas, by surprise. ${ }^{14}$ Later in the month, in an interview with Australian correspondents in Jakarta, Habibie said that in exchange for the granting of special status, the UN would have to recognise integration and 'the whole world should stop making problems'. ${ }^{15}$ Alatas soon produced a proposal for 'wide autonomy' which would go far beyond the largely nominal autonomy enjoyed by Jakarta, Aceh and Yogyakarta. East Timor's autonomy would not include foreign affairs, defence and security, and finance but might cover such areas as the economy, education and culture. ${ }^{16}$ Habibie seems to have believed that the granting of special autonomy to East Timor would undermine East Timorese resistance to Jakarta's rule and win the endorsement of the international community.

The president's offer of autonomy was greeted by a large demonstration in Dili on 23 June demanding full independence but senior anti-Jakarta leaders were opposed to an early referendum. Bishop Belo declared that 'I do not agree with a referendum now'. 'According to me', he said, 'okay, (in) 10 years, 15 years you can decide it'. ${ }^{17}$ Former Governor, Mario Carrascalão, was also opposed to an early referendum. 'If we want to hold it now, it would be suicide', he said. ${ }^{18}$ From his prison, Xanana Gusmão also said that there was no need to hold a referendum immediately as 'during the next 5 to 10 years there are several things that need to be done by the Indonesian government in order to prepare East Timor for a referendum'. ${ }^{19}$ At the UN, the East

12 Australian, 4 June 1998.

13 Reuters in Canberra Times, 10 June 1998.

14 President Habibie's foreign policy advisor, Dewi Fortuna Anwar, had to remind the President after the $\mathrm{BBC}$ interview that he should inform the Foreign Minister about his spontaneous offer (interview, 29 July 1999).

15 Sunday Age, 21 June 1998.

16 Antara, 25 June 1998.

17 Australian, 15 June 1998.

18 Kompas, 15 June 1998.

19 Tempo, 27 June 1998. 
Timor resistance's overseas spokesman, José Ramos Horta, urged that a referendum be held after a transition of 'two, three, four, five years' ${ }^{20}$

Habibie's offer and the positive response of Bishop Belo and other leaders gave new impetus to the slow-moving UN-sponsored tripartite talks on East Timor between the Indonesian and Portuguese Foreign Ministers that had commenced in 1992. During the latter part of the year, the two sides drew closer as both accepted the special autonomy idea in which East Timor would exercise authority in all fields except foreign affairs, defence and security, and finance. The unresolved difference, however, lay in whether such autonomy would represent a 'final solution', as the Indonesians insisted, or whether it was just a step toward a referendum, the position that the Portuguese defended.

\section{The 'popular consultation' proposal}

The tripartite talks had reached an impasse when, at the end of the year, the Australian government intervened. In a confidential letter sent to Habibie in December, the Australian Prime Minister, John Howard, suggested that some form of act of self-determination be offered to East Timor after a lengthy period of autonomy. ${ }^{21}$ Howard's proposal in effect endorsed the position of Portugal and the East Timorese resistance. Habibie was infuriated by Howard's letter which, by making a comparison with French policy in New Caledonia, was seen by Habibie as implying that Indonesia was a colonial power in East Timor. Although Habibie angrily rejected Howard's proposal, its significance lay less in its content than in the fact that Australia was the only 'Western' country that had explicitly recognised Indonesian sovereignty over East Timor. ${ }^{22}$ The changed Australian stance seems to have triggered a rethinking of Indonesia's position and, following a cabinet meeting on 27 January 1999, the Indonesian government announced that it would give the people of East Timor the opportunity to accept or reject its autonomy

20 AFP, 1 July 1998.

21 Much of Howard's letter is quoted by Paul Kelly in 'Letter that sparked the meltdown', Australian, 6 October 1999.

22 According to Alatas, Howard's proposal 'made Pak Habibie mad, it made Pak Habibie angry, because it came from Australia. Why should Australia get involved?', Jakarta Post, 2 November 1999. 
proposal later in the year. If they rejected the proposal, the government would recommend to the forthcoming session of the People's Consultative Assembly (MPR) that East Timor be permitted to withdraw from the Republic of Indonesia.

After receiving Howard's letter Habibie called together senior cabinet ministers, including General Wiranto, the Minister for Defence and Security and Commander of the TNI, Ali Alatas and Muladi, on 1 January to discuss the possibility of holding a referendum. ${ }^{23}$ Eventually the new policy was finalised by the cabinet's Political and Security Affairs Committee, of which both Wiranto and General Feisal Tanjung, the previous Commander of the TNI and current Co-ordinating Minister for Political and Security Affairs, were members. It was then discussed in a full cabinet meeting at which no fundamental objections appear to have been raised. Much later, however, after appearing before the Indonesian government's Commission of Inquiry into Human Rights Violations (KPP-HAM) in East Timor, Alatas told reporters that 'Although I defended the view that there should be no alternative to Option 1 (wide autonomy), I was outvoted in the meeting. ${ }^{24}$ In a newspaper interview, he said that he had 'advised, among other things, OK we can solve it, but isn't it premature. ${ }^{25}$ In explaining the policy publicly at the time, Alatas said that holding a referendum after 5-10 years would only exacerbate conflict and could even lead to civil war. Further, he implied that Indonesia did not want to subsidise East Timor for a long period and then see it leave the Republic. ${ }^{26}$ It appears that most ministers hoped that such a vote would be in favour of integration although a few weeks later Habibie himself hinted that the best solution was 'to grant independence so that we can concentrate on the other 26 provinces that already provide enough problems'. ${ }^{27}$

The details of the planned 'popular consultation' - as the Indonesians preferred to call it - were finally worked out in the 5 May Agreement - one dealing with the consultation itself and the other with security arrangements - signed by the Indonesian and

23 Don Greenlees, 'Howard letter delivered revolution', Australian, 27 January 2000. The heading of this article is misleading, to say the least.

24 Media Indonesia, 6 January 2000.

25 Jakarta Post, 2 November 1999.

26 Kompas, Media Indonesia, 28 January 1999.

27 Kompas, 12 February 1999. 
Portuguese foreign ministers. The referendum was to be conducted by the United Nations Mission in East Timor (UNAMET) with the support of police and military observers. Despite pressure to place international peacekeeping forces in East Timor during the ballot, the agreement entrusted the Indonesian police with the responsibility of ensuring a 'secure environment devoid of violence or of other forms of intimidation'. ${ }^{28}$

Why did the military accept President Habibie's policy? The military had been strongly committed to retaining East Timor as part of Indonesia. Certainly some military officers had recognised that a change in approach was needed but there had been no sign of willingness to consider a free vote to determine the future of East Timor. However, both Generals Wiranto and Faisal Tanjung had participated in the discussions that led to the announcement of the new policy and had apparently not protested. Wiranto's only public condition was that the correctness of the original intervention in East Timor in 1975 should not be questioned - in view of the sacrifices made by military personnel during the previous two decades. ${ }^{29}$ Of the military officers in the cabinet, it seems that only Lt. Gen. Hendropriyono, the Minister for Transmigration, had expressed concern and a few weeks later he said publicly that the holding of a referendum would increase the level of intimidation and 'bring disaster to the people of East Timor'. ${ }^{30}$

Did this mean that the military leadership supported the holding of the referendum? In retrospect, it seems that they did indeed accept the referendum but saw it as an opportunity to settle the East Timor issue once and for all by making sure that the vote would be in favour of continued integration with Indonesia. The stipulation in the 5 May Agreement that "The absolute neutrality of the TNI and the Indonesian Police is essential', was to be totally disregarded. Although the military leadership accepted the new policy, military officers in general were very unhappy about the prospect of a referendum in East Timor but there was no open military protest against the new policy. In any case, at that time, the military already had its hands full with an intensifying war against separatists in Aceh, increasingly vicious religious and ethnic conflict in Maluku and West Kalimantan, and growing restiveness throughout Indonesia.

29 Kompas, 29 January 1999.

30 Kompas, 12 February 1999. 


\section{The military role in the referendum}

Under the overall command of General Wiranto as Commander of the TNI, the officer with primary responsibility for military operations in East Timor was Maj. Gen. Adam Damiri, the commander of the army's Udayana Military Regional Command IX (Kodam) based in Bali. The officer directly in command in East Timor was Col. Tono Suratman, the commander of the Wiradharma Military Resort Command 164 (Korem) based in Dili. Beneath him at the kabupaten level were thirteen Military District Commands (Kodim), each headed by a lieutenant-colonel, and a network of Military Rayon Commands (Koramil) at the kecamatan level. Another senior officer involved in East Timor was the former head of military intelligence (BAIS), Maj. Gen. Zacky Anwar Makarim, who was formally appointed as Liaison Officer to UNAMET. Damiri, Suratman and Makarim had all been regarded as close to Lt. Gen. Prabowo Subianto, the Kostrad commander whom Wiranto dismissed immediately after the resignation of Prabowo's father-in-law, President Soeharto, in May 1998.

The military had always been the controlling political force in East Timor. Until the signing of the 5 May Agreement, internal security was the responsibility of the army while the police played only a subordinate role. The military had always worked closely with the pro-integration local elite. The governor and the thirteen bupati were all closely allied with the military and appointed with military endorsement. Under the 5 May Agreement, however, responsibility for security was transferred to the police, although TNI forces remained in East Timor.

There had always been considerable confusion about the exact number of troops in East Timor, as official statements were not always consistent with each other. According to credible leaked documents, the total number of military forces (including police) in East Timor in late 1998 was 17914 , consisting of 9976 'organic' (i.e. local) troops and 7938 troops brought in from elsewhere in Indonesia. In addition, if 3711 civilian personnel serving in civilian units are counted, the total number of forces under military command in late 1998 was $21625 .^{31}$

The civilian units under direct and formal military command known as wanra (Perlawanan Rakyat - People's Resistance) - were armed for operations against rebel forces. Naturally the members of

31 I have corrected small arithmetical errors in one of these documents. 
wanra were recruited from that part of society which was loyal to Jakarta. In the mid-1990s, however, new paramilitary groups were sponsored by the military but, in contrast to wanra, they were not formally incorporated into the military structure. These new units were used to terrorise and intimidate supporters of independence, most notoriously through so-called 'ninja' operations. The most prominent unit was the Gadapaksi (Gada Pemuda Penegak IntegrasiYouth Guard to Uphold Integration) sponsored by Col. Prabowo, then assigned to the Special Forces (Kopassus). By 1998 so-called militias were operating in all 13 of East Timor's kabupaten. In many cases, the participants in the new militia were also members, or at least related to members, of the wanra. Eventually the various militias were loosely brought together as the Pasukan Pejuang Integrasi (PPI - Fighters for Integration Force) under the leadership of the former bupati of Bobonaro, João Taveres, as their Panglima Perang (War Commander). The PPI itself claimed that the total militia strength was over 50000 but an Australian diplomat estimated that there were only about 3000 in various militia and another 3000 remnants of Gadapaksi. In addition there were about 2-3000 in wanra. ${ }^{32}$

It was obvious that the militia forces were closely linked to military officers and government officials. Senior officers and officials made no secret of their good relations with the militia leaders. Thus, Maj. Gen. Adam Damiri, the Udayana commander, was quoted as saying that João Taveres' appointment as War Commander of the PPI is an appropriate thing and the military will not question it.. ${ }^{33}$ In later testimony before the KPP-HAM, Adam Damiri said meetings between military officers and what he called Pam Swakarsa (civilian security forces) were routine in order to discuss local security conditions. ${ }^{34}$ Leading military officers often appeared at militia rallies. For example, the Korem commander, Col. Tono Suratman, attended a militia rally at Maliana in April, only a few days after another militia unit had killed and wounded independence supporters in a church at Liquiça. ${ }^{35}$ On another occasion Tono Suratman, the Governor Abilio Soares, and the Police Chief, Timbul Silaen, attended a ceremony in 
Ambeno where the local branch of the pro-independence organisation, CNRT, was forced to dissolve itself. ${ }^{36}$ Local government officials also co-operated closely with militia leaders. According to the testimony before the KPP-HAM of both Col. Tono Suratman and the former bupati of Dili, Domingos Soares, the Pam Swakarsa or militias were under the supervision of the police and financed by the local governments. ${ }^{37}$ In June, the bupati of Dili, Domingos Soares, appointed Eurico Guterres, the head of Aitarak militia which had recently rampaged through Dili, as co-ordinator for public security in Dili. ${ }^{38}$ Guterres was also appointed as Tavares' deputy in the PPI. And João Tavares, Eurico Guterres and another militia leader, Manuel da Souza, were nominated as Golkar candidates in the June election. ${ }^{39}$

The TNI was often accused of supplying the militia with arms. For example, the general secretary of the Indonesian National Human Rights Commission (Komnas-HAM), Clementino Dos Reis Amaral himself an East Timorese - claimed in January 1999 that the TNI had been supplying militias with weapons since late in $1998 .{ }^{40}$ While it is true that some militia members were observed carrying modern weapons, most militia, however, were armed with home-made rifles, machetes, spears and knives. Faced with accusations of supplying arms to the militia, the military admitted that the wanra routinely used arms under its supervision but denied supplying arms to the 'private' militias. However, given the overlap in membership between wanra and the militias, it was inevitable that some modern weapons were transferred to militia members. And it was impossible to believe that military officers were not aware of this. ${ }^{41}$

36 Kompas, 3 May 1999.

37 Kompas, 22 and 28 December 1999. This claim, however, was denied by the militia chief, João Taveres. The former Chief of Police in East Timor, Col. Timbul Silaen, also denied the involvement of the police in training or supervising the militias. Kompas, 29 December 1999.

38 Australian, 3 June 1999.

39 Ibid.

40 Sydney Morning Herald, 28 January 1999.

41 In an interview in Jakarta in March 1999, a senior lieutenant-general said: In Indonesia we cannot assume that whatever the commander decides is automatically done on the ground. It is quite likely that local military officers are allowing pro-integrationists to have weapons. After all, they have been their friends for many years. 
Since the latter part of 1998 conflict between the pro- and antiintegration sides had been increasing and physical clashes had become commonplace. One consequence of rising violence was an increase in the number of refugees either fleeing into the hills or seeking protection in the larger towns. It was widely suspected that prointegration militias were driving pro-independence villagers away from their homes in order to disrupt the registration of voters for the referendum. The Catholic agency, Caritas, also claimed that refugees in Dili were forced into militia-controlled camps where they had to swear allegiance to Indonesia in order to get food. ${ }^{42}$

That the Indonesian side was attempting to control the supply of daily necessities was indicated in a leaked letter apparently written by Maj. Gen. (ret.) Garnadi to his superior, the Co-ordinating Minister for Political and Security Affairs, General Feisal Tanjung. ${ }^{43}$ According to the letter,

The job of winning over the people of East Timor to support Special Autonomy is in fact not all that difficult because we are competing for floating voters whose demands are very simple, that is the supply of food and medicine. They will follow whoever gives them food and medicine.

But the letter indicated concern because the government's expected monopoly over the distribution of food aid had been broken by the large number of foreign-backed NGOs that were also distributing food and medicine to refugees. The letter argued that 'there is no distinction between a refugee and a hungry person; in fact a hungry man can be made a refugee in a moment under pressure from the anti-integration group'. On the other hand, it complained that 'we are always late whereas the anti-integration side can make use of the opportunity provided by the presence of UNAMET with its extra role as if they are guardian angels (dewa menolong)'. ${ }^{44}$ What the letter meant was that the presence of UNAMET made it easier for foreignsupported pro-independence NGOs to supply food to refugees and thus enable them to avoid dependence on government aid.

42 Australian, 27 May 1999.

43 At the KPP-HAM enquiry, Garnadi, who had been the Deputy Chairman of the Task Force to Implement the Consultation in East Timor (Satgas P3TT), acknowledged that the signature resembled his and that the stamp seemed genuine but he denied that he wrote it. The enquiry seemed to treat the letter itself as genuine (Republika, 29 December 1999).

44 The leaked Garnadi letter is dated 3 July 1999. 
The pro-integration side accused UNAMET of being biased in favour of independence. In particular they claimed that many of its local staff of 500 were known to be supporters of independence. ${ }^{45}$ They also said that UNAMET staff themselves were involved in distributing food to supporters of independence. For example, Domingo Soares accused UNAMET of supplying food to proCNRT refugees in Sare early in July. ${ }^{46}$ Soares' criticism followed an incident on 4 July at Liquiça. A team of NGOs took 13 truck-loads of food and medicine to about 3000 refugees in Fare and Faulara in Ermera kabupaten. For protection they were accompanied by personnel from UNAMET and UNHCR. But on their return journey through Liquiça they were attacked by members of the Besi Merah Putih militia armed with firearms, parang and stones. One member of the NGO party was shot, four were wounded and the UNAMET car was damaged but neither the military nor the police intervened. ${ }^{47}$ The involvement of UNAMET in this incident was criticised by the police chief, Col. Timbul Silaen, who said that UNAMET's authority was limited to holding the 'popular consultation' and did not include the distribution of humanitarian aid. ${ }^{48}$

There is no doubt that both sides were involved in violence against each other but the violence of one side was tolerated by the Indonesian security forces. On many occasions foreign observers - journalists, diplomats, aid workers and UNAMET officials - witnessed incidents in which police did nothing to prevent violence perpetrated by members of pro-integration militias. In May the UN Secretary-General told the Security Council that 'credible reports continue to be received of political violence, including intimidation and killings, by armed militias against unarmed pro-independence civilians' and he noted that the militias seemed 'to be operating with the acquiescence of elements of the army'. ${ }^{49}$

The strategy of the military leadership in Jakarta was to allow local commanders to use the military-sponsored militias to terrorise the population in order to ensure a vote in favour of autonomy. But, despite their endorsement of intimidatory tactics, they did not want 45 Australian, 10-11 July 1999.

46 Kompas, 6 July 1999.

47 Kompas, 5 July 1999; Yayasan Hak statement, 4 July 1999.

48 Kompas, 6 July 1999.

49 Australian, 26 May 1999. 
the violence to rise to a point where the referendum would lose all international credibility. General Wiranto assured his cabinet colleagues that the violence could be controlled and on 21 April, three days after a murderous rampage through Dili by the Aitarak militia, he organised the signing of a peace pact in Bishop Belo's house between the two sides with Tavares and Domingos Soares signing for the integrationists and Xanana Gusmão, still in prison in Jakarta, signing for the CNRT. But the violence continued and another TNI-sponsored meeting between the two sides was held in Jakarta on 15 June. Wiranto also supported the second church-sponsored 'Dare meeting' in Jakarta on 28-30 June which was attended by thirty participants from each side.

In the end, the military-supported intimidation of voters did not produce a pro-integration vote. On the contrary, it may have even contributed to the overwhelming rejection of the autonomy option by 78.5 per cent of the voters. As one pro-independence leader explained,

We practically did no campaigning at all to win the recent consultation ... because for more than twenty years anti-Indonesian attitudes have been created by the behaviour of the TNI toward our society, to our coffee plantations, to our cattle, and to the social fabric which is the foundation of our social life..$^{50}$

\section{Post-referendum destruction}

There can be no doubt that the pre-referendum intimidation of voters was part of General Wiranto's plan to secure a vote in favour of autonomy. But did that plan also envisage the destruction and killing that followed the vote against autonomy?

Following the completion of polling on 30 August, General Wiranto complimented the UNAMET on carrying out its responsibilities 'successfully'. ${ }^{51}$ But, on the ground in East Timor, the pro-Jakarta militias embarked on a campaign of killing and destruction even before the announcement of the result on 4 September. Marauding bands of militia members attacked supporters of independence and destroyed much of the infrastructure of East Timor. Although the number killed was probably in the hundreds rather than early estimates of thousands, the early estimates of hundreds of thousands of people being forced to flee their homes turned out to

50 Republika, 22 September 1999.

51 Kompas, 31 August 1999. 
be accurate. According to Indonesian figures, about 240000 refugees entered West Timor while others estimated that several hundred thousand sought refuge in the hills. It was reported that about 70-80 per cent of Dili's business district had been destroyed and 50 per cent of homes had been burnt. The Indonesian newspaper, Kompas, described how 'only ruins remain of the lovely and glittering town of Dili, ${ }^{52}$ Other towns and villages suffered a similar fate.

Foreign observers, such as those of the Carter Center, reported that their members have on numerous occasions witnessed militia members perpetrating acts of violence in full view of heavily-armed police and military personnel who either stand by and watch or actively assist the militias, ${ }^{53}$ But it was not only foreigners who were shocked by what they saw. Kompas reported that 'The Indonesian security forces often seemed to do nothing when violence broke out ${ }^{54}$ and several Indonesian journalists' associations claimed that 'violent attacks on journalists were launched quite openly by pro-autonomy militia without the slightest attempt by the police or TNI to prevent them or to take action against the perpetrators'. ${ }^{55}$ Komnas-HAM also noted that terrorist activities took place 'directly witnessed and permitted by members of the security forces. ${ }^{56}$ Suara Pembaruan reported that 'The police, military and militia are seen to have taken control of the streets. The police can be seen greeting and chatting with militia members'. ${ }^{57}$

General Wiranto, however, adamantly denied that his troops were supporting the militias. 'It is not possible that the TNI is backing the militias', he declared. 'From the beginning we have said we are neutral', he asserted somewhat unconvincingly. ${ }^{58}$ The security problem in East Timor, he explained later, was due to the dissatisfaction of the prointegration side with what they saw as electoral violations perpetrated by UNAMET. ${ }^{59}$ He even suggested that 'This dissatisfaction is proper, and has been expressed in the form of spontaneous actions ${ }^{60}{ }^{60}$ On

52 Kompas, 12 September 1999.

53 Carter Center Weekly Report on East Timor, No. 18, 6 September 1999.

54 Kompas, 2 September 1999.

55 Kompas, 3 September 1999.

56 Kompas, 9 September 1999.

57 Suara Pembaruan, 5 September 1999.

58 Kompas, 3 September 1999.

59 Kompas, 7 September 1999.

60 Kompas, 2 September 1999. 
another occasion he told a journalist that 'You can see and feel yourself how a disappointed person, who has been treated unjustly before their own eyes, whose complaints have been ignored, in the end will be disappointed and angry. Then they express their disappointment. ${ }^{61}$

Wiranto was referring to the pro-integration side's claim that the referendum had been conducted fraudulently. The bupati of Dili, Domingos Soares, detected an 'international conspiracy' behind the defeat while the pro-integration Forum Persatuan dan Keadilan (Unity and Justice Forum) accused UNAMET of bias. It was alleged that UNAMET's local staff were mainly supporters of independence while it had refused to accept observers from Indonesia. ${ }^{62}$ One respected Indonesian observer, Benyamin Mangkoedilaga, of the Komnas-HAM, supported these accusations. He said 'violations and injustices really happened and were done in front of our eyes by certain UNAMET individuals' who were locally recruited and 'obviously pro-independence'. ${ }^{63}$

The pro-independence militia leaders threatened to go to war if the referendum decision were implemented. João Tavares, the War Commander of the PPI, announced that 'we will declare war and take up arms'. His colleague, the governor of East Timor, Abilio Soares, was equally bellicose. 'We are ready for war', he said but also suggested the partitioning of East Timor as an alternative. ${ }^{64}$

Was the post-referendum killing and destruction a spontaneous reaction of disappointed supporters of integration as claimed by General Wiranto? Or was it part of a contingency plan prepared in advance by the TNI? And if part of a TNI contingency plan, at what level in the TNI was it prepared?

The much-quoted 'Garnadi document', dated 3 July, has been interpreted as evidence that the destruction was planned at the highest level in the Indonesian government. But the document is open to a less culpable interpretation. Its author foresaw the possibility that the vote might be against autonomy and, therefore, proposed a 61 Republika, 5 October 1999.

62 Waspada, 6 September 1999. UNAMET had rejected 24 Indonesian NGOs which offered to send referendum monitors on the grounds that some were not genuinely independent of the Indonesian government. Kompas, 26 August 1999.

63 Kompas, 10 September 1999.

64 Suara Pembaruan, 5 September 1999. 
contingency plan to meet such an eventuality. The plan envisaged the evacuation of vulnerable civil servants and immigrants before the announcement of the result and the preparation of facilities for refugees in West Timor. It also proposed that preparations be made to secure a route for withdrawal including if possible, the destruction of vital facilities'. Later Human Rights Watch (HRW) publicised a telegram sent on 5 May (the day on which the UN-sponsored agreement between Indonesia and Portugal was signed) by the Deputy Chief of Staff of the army, Lt. Gen. Johny Lumintang, to the Bali Regional Commander in which he instructed that preparations be made to evacuate refugees in the event of the people voting against autonomy. ${ }^{65}$

Neither the Garnadi document's proposals nor Lumintang's telegram are obvious blueprints for the destruction that followed the announcement of the referendum result. Indonesian elite opinion at the time was quite genuinely expecting the referendum to trigger a civil war. Although most were confident that the pro-integration side would win, the Garnadi memo explicitly envisaged a situation in which autonomy was rejected and the pro-integration minority was being massacred by the victorious pro-independence majority. The letter can be read as proposing that 'vital facilities' such as bridges, communications equipment etc. should be destroyed to allow prointegration supporters to flee to safety in West Timor. There is nothing in the letter to suggest the 'scorched earth' destruction - including public buildings, houses, shops, hotels and so on, let alone mass killings - which actually happened. Similarly the evacuation envisaged in Lumintang's telegram is explicitly placed in the context of measures to prevent the widely expected civil war.

This does not mean, of course, that TNI officers on the ground in East Timor had not given thought to exacting revenge if the vote went against integration. In May, The Australian published a story about a document which said 'Massacres should be carried out from village to village soon after the announcement of the ballot if the proindependence supporters win'. This document also promised aid in the form of M-16 rifles as well as support from the air force ${ }^{66}$ But it is not clear that this was a real plan of action or just part of the general intimidation to persuade voters to support the autonomy 65 Human Rights Watch (HRW), Indonesia/East Timor: Forced Expulsions to West Timor and the Refugee Crisis, Vol. 11. No. 7(c). Appendix. 66 Australian, 24 May 1999. 
option. And even if some officers were considering such action, it does not necessarily show that the TNI leadership was committed to this policy. In any case, in May the TNI leaders were still confident that the vote would be in favour of autonomy.

In August, however, as officers and militia members faced the increasing likelihood that the vote would go against them, there are more indications of plans to exact revenge on the pro-independence side. The disaffected former bupati of Covalima, Rui Lopes, claimed that shortly before the referendum military and police officers had ordered militias to attack the UNAMET office in Suai, burn the town and drive the population into West Timor. ${ }^{67}$ Rui Lopes' claim was made after reports that about 100 people, including three priests, were killed by militias in Suai on 6 September. Leaked reports from foreign police personnel attached to UNAMET also described plans prepared by local military and police offers to attack pro-independence supporters if the vote was in favour of independence. ${ }^{68}$ This suggests that military officers and their militia friends planned some sort of retaliation but it leaves open the question of whether the violence had been planned long in advance at the highest level in the TNI.

As the referendum approached, the Indonesian government made preparations for a possible influx of refugees into West Timor. The Justice Minister, Muladi, said that he expected 200000 or more refugees to flee from East Timor if the pro-independence side won and the Minister for Social Affairs, Yustika Baharsyah, announced that her department had prepared facilities for 200000 refugees in West Timor. ${ }^{69}$ It has sometimes been suggested that such large-scale preparations indicate that the post-referendum destruction was planned well in advance. But it seems no less plausible to believe that the Indonesian government was worried that the outbreak of civil war would force refugees to flee. That facilities for 200000 refugees were prepared in advance does not indicate that the mass destruction by pro-Jakarta militias was planned by the government.

As it happened, the post-referendum chaos was indeed accompanied by a huge exodus of refugees to West Timor. Although many were forced to leave by militia and military threats, it also needs to be recognised that a substantial number were supporters of 67 Carter Center East Timor Weekly Report, No. 9, 13 September 1999.

68 Paul Daley, 'What the UN knew', Age, 9 October 1999.

69 Kompas, 3 September 1999. 
autonomy who may well have felt a genuine fear for their safety after the referendum. In all about 240000 refugees - about one-third of the indigenous population - were transported to West Timor. It has been pointed out that this number is much larger than the 94000 who voted for autonomy and the conclusion has sometimes been drawn that most of the refugees, therefore, were coerced supporters of independence. But this overlooks the fact that many refugees were children who had not been eligible to vote in the referendum. If we assume for simple illustrative purposes that all 94000 supporters of autonomy fled to West Timor and took their children with them, the total number of 'willing' refugees could easily have exceeded 200000 . It is possible that many of these refugees had been convinced that a civil war was about to break out in which they would be subjected to violence by the victorious majority. They therefore gratefully accepted TNI assistance to escape to West Timor. After several months in refugee camps and having seen the restoration of order in East Timor, many decided to return although by January 2000 about 50000 refugees had opted to remain in Indonesia.

Although an uncertain proportion of refugees was 'willing', there is also plenty of evidence indicating that the military was involved in forcing many others to leave for West Timor. Interviews conducted by HRW in November with returning refugees in Dili indicated that many had been forced by militia members to move to West Timor during the three weeks after the referendum before the arrival of Interfet troops on 20 September. Refugees told HRW that militias, 'often accompanied by local army officers, forced families at gunpoint into the district or subdistrict army headquarters', after which their houses were burned and they were taken by car or truck to West Timor. ${ }^{70}$ The HRW account is consistent with the observations of UNAMET officials and Western journalists. It is also supported by reports in the Indonesian press. For example a Kompas reporter asked refugees in Dili why they were leaving. One answered, 'Because I was told to leave. They said it would be better if we leave..'

But, was the forced evacuation of refugees part of a long-term plan to destroy East Timor after the referendum? HRW argues that 'The logistics involved, the similarity of the process from one end of East Timor to the other, and direct witness testimony all point to a planned and systematically implemented operation'. ${ }^{72}$ As discussed 70 HRW, op.cit.

71 Kompas, 19 September 1999.

72 HRW, op.cit. 
above, there is in fact no question that the military had given consideration to the possibility of mass evacuation and was prepared to evacuate over 200000 people to West Timor. What needs to be explained is why the military felt it necessary to force so many people to become 'unwilling' refugees.

The available evidence is not sufficient to provide convincing support for the view that the destruction that followed the referendum was part of a long prepared military plan. It seems that many officers, at least until about July or early August, were still quite confident that the intimidation carried out by the militias under their guidance would secure a pro-autonomy vote. It was only as the referendum drew close that most must have realised that the referendum might indeed be lost. But even then it seems that they expected the result to be quite close. It is of course possible that military officers planned to encourage militia violence well in advance but it seems quite likely that their support for the destruction, killing and forced deportation was a reaction to their realisation that the referendum would be lost.

Even on the evening of the ballot, pro-integration supporters had begun their campaign of killing and destruction. That the TNI and police made no serious attempt to prevent the violence is obvious. That some elements in the military - particularly local East Timorese soldiers participated in the violence is also clear. And there are indications in some areas at least - such as Suai - that military officers actively encouraged the violence. That the violence took place throughout East Timor indicates a degree of territory-wide co-ordination that would have required military approval and probably assistance. And it is clear that TNI personnel played a major role in forcing unwilling refugees to cross into West Timor.

At this stage we can only speculate about military motives.

First, the TNI had worked closely for two decades with the prointegration sector of society from which the militia members were drawn. Why were the security forces unable to stop the rampaging militias? According to President Habibie, 'It must be acknowledged that they (TNI) faced obstacles which were more psychological than military. ${ }^{73}$ The loyal support of wanra and the militias over many years had imposed on the TNI what Wiranto called a 'psychological burden ... because they had to confront a section of the Indonesian people themselves who felt that they had been treated unjustly. ${ }^{74}$ 73 Republika, 13 September 1999.

74 Suara Pembaruan, 20 September 1999. 
Wiranto said it is not possible that our close relationship with the fighters for integration could be cut off just like that. We could not avoid this and we honestly admit it. ${ }^{75}$ In a later newspaper interview he even asked 'Must we confront them with force? ${ }^{? 6}$ Wiranto's loyalty to the TNI's militia allies was such that he could not bring himself to turn on them in the new circumstances. But, as an editorial in the Jakarta Post asked, if Wiranto knew that his troops could not control the militias, why did he accept responsibility for maintaining order under the 5 May Agreement in the first place ${ }^{77}$ And, the 'psychological burden' does not explain the active involvement of TNI troops in forcing refugees into West Timor.

A second possible explanation is also psychological. The TNI leadership had accepted Habibie's policy of holding a referendum because they were confident that they could secure a victory for the pro-autonomy side. Military officers had also conveyed that sense of confidence to the pro-integration East Timorese and to their civilian colleagues in Jakarta. Thus it came as a huge shock to most Indonesians when the pro-autonomy side was not only defeated but defeated by a margin of nearly four to one. As Ali Alatas explained much later, 'They always reported that we were going to win. So they too were shocked, maybe ashamed.' The TNI leaders then claimed that they lost because of electoral violations permitted by UNAMET but, as Alatas again pointed out, the violations were 'not to the point that you can change 78 to 22 per cent'. ${ }^{78}$ Angry and humiliated by their overwhelming defeat, it has been suggested that military officers then gave a free hand to their men and the militias to exact some sort of revenge on the East Timorese people who had so decisively rejected integration with Indonesia.

Another explanation suggests more rational calculation. Indonesia had always justified its initial intervention in East Timor as motivated by the need to stop a civil war in East Timor. And they continued to justify the heavy military presence in East Timor as being necessary to prevent the resumption of that war. After Habibie introduced his new policy in January 1999, many military officers continued to argue that a civil war would break out if East Timor won its independence. The overwhelming vote

76 Republika, 5 October 1999.

77 Jakarta Post, 13 September 1999.

78 Jakarta Post, 2 November 1999. 
in favour of independence, however, undermined much of the credibility of the 'civil-war' justification. Instead of a neutral arbiter between more or less evenly matched warring factions, the TNI now appeared to be the oppressor of the vast majority of the people in order to protect the interests of a small minority. In a desperate attempt to legitimise its long involvement the TNI may have aimed to convince not only the rest of the world but also the Indonesian people that there really was a civil war by themselves creating a huge exodus of refugees. Having announced preparations to receive 200000 refugees, the TNI had to make sure that the refugee camps were filled.

A fourth explanation, often put forward by foreign observers, was that the destruction of East Timor was intended as a deliberate warning to other restive provinces which might seek independence, particularly Aceh and Irian Jaya. If, however, as suggested above, the decision to allow the destruction to take place was taken rather late in the process - because Indonesian leaders had been confident of winning until the last month or so - it seems more likely that the policy was driven by the situation in East Timor itself rather than possible consequences in faraway Aceh and Irian Jaya. The impact on other provinces was probably no more than a secondary consideration.

At what level was the decision taken to permit the destruction of East Timor? General Wiranto himself has stated that the TNI's 'psychological burden' prevented it from taking measures to repress the rampaging militias. It is obvious, however, that military officers in East Timor gave explicit support and encouragement to the militias and that soldiers, especially those of East Timorese background, participated in the destruction. Did orders come from Jakarta, Bali, Dili or local commanders? Both the United Nations and the Indonesian government established commissions of inquiry which reported on these questions. The answers will only be clear if charges are laid and officers brought to court.

\section{Curbing the violence and the intervention of the UN}

There were signs that the massive destruction taking place in East Timor was going far beyond anything that members of the government had expected. On 5 September, President Habibie sent the Political and Security Affairs group of ministers (including Faisal Tanjung, Wiranto and Alatas) to East Timor where they met representatives of both the pro- and anti- 
independence sides but reportedly did not venture outside the airport. In a later interview Alatas said of the post-referendum violence that 'It shocked the world, it shocked us too frankly' and he asked 'why it was not stopped immediately. ${ }^{79}$ According to one report, militia leaders angrily confronted Wiranto and accused him and the government of betrayal. Wiranto, they apparently believed, had previously assured them that the referendum would result in a victory for autonomy.

At this point it seems that Wiranto began to take steps to regain control of the situation. He ordered six Kostrad battalions to go to East Timor and persuaded the President to introduce martial law in East Timor at midnight on 6-7 September. Earlier on 6 September, Habibie had raised the possibility of martial law at a meeting with the parliament (DPR) but the response was generally negative. He then discussed the issue in cabinet but failed to obtain endorsement ${ }^{80}$ - although one inside source asserts that the proposal was not specifically rejected by the cabinet. However, in briefing the press, the Minister for Information, Lt Gen Yunus Yosfiah, gave the impression that the cabinet had rejected the martial law option. Thus, when the introduction of martial law was announced at midnight, it seemed that General Wiranto had imposed his own wishes on the president. Rumours even circulated about the possibility of a military coup.

In fact there had been no serious conflict between Habibie and Wiranto on this issue. Habibie initially felt constrained by the 5 May Agreement that required Indonesia to use the police, not the army, to maintain security. He had then contacted the UN Secretary-General and explained that the police no longer had the capacity to control the situation. Under Indonesia's emergency law, it was possible to declare a civil emergency which would place full power in the hands of the regional governor but the governor, as noted above, was one of those threatening to launch a civil war. And, in any case, as Wiranto pointed out, 'the governor has already fled'. ${ }^{81}$ The only alternative, therefore, was to introduce martial law. Kofi Annan then accepted the declaration of martial law but warned that 'the international community will have to consider what other measures it can take if Indonesia fails to bring the situation under control within 48 hours' ${ }^{82}$

79 Jakarta Post, 2 November 1999.

80 Kompas, 7 and 8 September 1999.

81 Republika, 13 September 1999.

82 Keith Richburg, 'Mayhem Continues in East Timor', Washington Post, 8 September 1999. 
Wiranto appointed the army's Assistant for Operations and former East Timor Korem commander, Maj. Gen. Kiki Syahnakri, as martial law commander. It seems that by now Wiranto was persuaded that Indonesia's international reputation was at stake and that firm action should be taken to restore order. Pro-integration militia leaders were called to a meeting with Maj. Gen. Adam Damiri in Bali where, according to Wiranto, they were told that 'there is no longer a need to engage in actions or activities that violate the law'. ${ }^{83}$ João Tavares then announced that all operations ceased on 9 September. ${ }^{84}$ Wiranto himself met Guterres and Abilio in Dili on 11 September and reiterated that all activities which 'ruin the good name of East Timor' should stop. ${ }^{85}$

By now the international condemnation - fed by newspaper reports and television broadcasts throughout the world - was putting enormous pressure on the Indonesian government. In the face of demands to accept international troops to restore order, Indonesian leaders continued to insist that they could do the job. Wiranto declared that 'We have the capacity to handle the situation' ${ }^{86}$ and Alatas pleaded that 'For Indonesia, we have pride that we can carry out our obligations and we request that we be given the opportunity to complete that task'. He added that 'it will only create a very bad image if, before we are given the opportunity, we give up and agree to the sending of foreign troops although according to the international agreement, it is in fact our task to carry out that duty. ${ }^{87}$

In response to growing international concern, the UN Security Council sent a five-member mission headed by the British ambassador to the UN, Sir Jeremy Greenstock, to Indonesia where they visited Dili on 11 September in the company of General Wiranto. Initially Wiranto told the mission that there was no need for international troops. 'Conditions in East Timor are already good', he said, 'there is no more killing, burning and destruction'. But, after accompanying the mission on their tour of Dili, he seemed to back down and agreed that 'The offer to speed up the entry of peacekeeping forces must be considered as one of the choices for the government of Indonesia'. ${ }^{8}$ The mission members were amazed by the destruction that they saw

83

84

85

86

87

88

AFX-Asia, 8 September 1999.

Kompas, 12 September 1999.

Kompas, 12 September 1999.

Washington Post, 8 September 1999.

Kompas, 10 September 1999.

Kompas, 12 September 1999. 
and noted that 'The mission had the distinct impression that when the General travelled to Dili along with the mission and toured the city, he had not been prepared for the extent of destruction'. They concluded that the Indonesian security forces were incapable of restoring order. The mission leader said that 'I don't think anybody here has any doubt that there has been complicity between elements of the defence forces and the militias. In some areas, there is no difference between them in terms of action and motivation'. The mission therefore recommended that an international force be sent to East Timor 'without delay'. It also recommended that 'apparent abuses of international humanitarian law' be investigated. ${ }^{89}$

As the violence in East Timor continued, the UN Secretary-General said that Indonesia would be responsible for 'crimes against humanity' if it did not immediately accept the dispatch of foreign troops. This was backed by the US President, Bill Clinton, who declared bluntly that the Indonesian military was backing the militias while the US ambassador to the UN, Richard Holbrooke, explicitly blamed the TNI 'under the leadership and command of General Wiranto' for what happened in East Timor. Meanwhile, the Chairman of the US Joint Chiefs of Staff, General Henry Shelton, had been speaking daily by telephone with Wiranto. Ominously the IMF suspended the visit of an aid team to Indonesia and both the IMF and World Bank expressed their concern about the situation in East Timor. ${ }^{90}$ Finally, on the evening of 12 September, the Indonesian cabinet agreed to accept the international force in East Timor.

On 15 September the UN Security Council authorised the formation of the International Force in East Timor (Interfet) to be commanded by Australian Major-General Peter Cosgrove with a Thai Deputy Commander. Around 4500 of its 7000 strength was Australian. Cosgrove arrived in East Timor on 19 September and troops began to land on 20 September. Cosgrove and the Indonesian commander, Kiki Syahnakri, seem to have co-operated well together. Although the 5 May Agreement provided for Indonesian forces to retain responsibility for security in East Timor until the MPR had made a final decision on East Timor's future, the Indonesian presence declined rapidly and all had left by early October.

89

90 Kompas, 11,12 September 1999. 
With the MPR preoccupied with its vote on President Habibie's 'accountability speech' on 19 October and the presidential election on 20 October, the reversal of the 1976 MPR decision incorporating East Timor into Indonesia was passed unanimously without debate by the weary MPR members shortly before midnight on 19 October 1999.

\section{Reference}

Saldanha, João Mariano de Sousa, 1994. The Political Economy of East Timor Development. Jakarta: Pustaka Sinar Harapan. 